\title{
STUDY KORELASI FAKTOR-FAKTOR YANG BERHUBUNGAN DENGAN KUALITAS HASIL BELAJAR MELALUI ORIENTASI MASA DEPAN PADA MAHASISWA POLITEKNIK KESEHATAN SURAKARTA TAHUN 2017
}

\author{
Dodiet Aditya Setyawan*1, Wiwik Setyaningsih $^{2}$, Ari Sarwanto ${ }^{3}$ \\ Poltekkes Kemenkes Surakarta Jurusan Terapi Wicara
}

Background: Achieving a good quality of a student's learning outcomes is influenced by many factors including intelligence, talent, interest and attention, motivation, ways and habits of learning, family and school environment. That is why the level of Intelligence Quotient (IQ) is not the only factor that determines one's success, because there are other influencing factors. This study aimed to determine the factors that influenced the quality of students' learning outcomes at Politeknik Kesehatan Surakarta. Methods: This study was a correlational descriptive study which is explanatory in nature that explains the relation between study variables through hypothesis testing. The approach method used in this study was cross sectional. This research was conducted in Politeknik Kesehatan Surakarta environment which consisted of 8 Departments with a total of 3,407 students. The sampling technique used to determine the number of samples in this study was Proportional Stratified Random Sampling, with a sample size of 358 respondents. While the data analysis plan was done descriptively, bivariate with Kendall's Tau technique. Results : The results of the study show that the factors which are proven to be significantly related to the students' learning outcomes quality in Politeknik Kesehatan Surakarta are Spiritual Intelligence ( $p=0.019)$; Motivation ( $p=0.031)$, Learning Habits $(p=0.037)$. Conclusion: Factors that are significantly related to the quality of learning outcomes in Politeknik Kesehatan Surakarta students include Spiritual Intelligence, Motivation, and Learning Habits. While the Spiritual Intelligence factor is not significantly related to the quality of students' learning outcomes at Politeknik Kesehatan Surakarta.

Keywords: Learning Outcomes Quality, Future Orientation, Students, Kecerdasasan Spiritual, Kecerdasan Emosional.

\section{PENDAHULUAN}

Setiap kegiatan pembelajaran tentunya selalu mengharapkan akan menghasilkan pembelajaran yang maksimal sehingga dapat mencetak lulusan yang berkualitas. Pencapaian kualitas hasil belajar yang baik dari seorang mahasiswa dipengaruhi oleh banyak faktor antara lain kecerdasan, bakat, minat dan perhatian, motivasi, cara dan kebiasaan belajar, lingkungan keluarga dan sekolah. (Syah, M., 2010).
Dalam pendidikan formal, belajar menunjukkan adanya perubahan yang sifatnya positif sehingga pada tahap akhir akan didapat keterampilan, kecakapan dan pengetahuan baru. Kualitas hasil dari proses belajar tersebut tercermin dalam prestasi belajarnya. Namun dalam upaya meraih prestasi belajar yang memuaskan dibutuhkan proses belajar yang baik. Proses belajar yang terjadi pada individu memang merupakan sesuatu yang penting 
karena melalui belajar individu mengenal lingkungannya dan menyesuaikan diri dengan lingkungan disekitarnya.

Banyak orang yang berpendapat bahwa untuk meraih prestasi yang tinggi dalam belajar, seseorang harus memiliki Intelligence Quotient (IQ) yang tinggi, karena inteligensi merupakan bekal potensial yang akan memudahkan dalam belajar dan pada gilirannya akan menghasilkan prestasi belajar yang optimal. (Sinetar, M., 2001). Kenyataannya, dalam proses belajar mengajar di sekolah sering ditemukan mahasiswa yang tidak dapat meraih prestasi belajar yang setara dengan kemampuan inteligensinya. Ada mahasiswa yang mempunyai kemampuan inteligensi tinggi tetapi memperoleh prestasi belajar yang relatif rendah, namun ada mahasiswa yang walaupun kemampuan inteligensinya relatif rendah, namun dapat meraih prestasi belajar yang relatif tinggi. Itu sebabnya taraf Intelligence Quotient (IQ) bukan merupakan satu-satunya faktor yang menentukan keberhasilan seseorang, karena ada faktor lain yang mempengaruhi.

Menurut Goleman (2000), kecerdasan intelektual (IQ) hanya menyumbang $20 \%$ bagi kesuksesan, sedangkan $80 \%$ adalah sumbangan faktor kekuatan-kekuatan lain, diantaranya adalah kecerdasan emosional atau Emotional Quotient (EQ), Spiritual Quotient (SQ), Motivasi, Minat, Kebiasaan Belajar, Kesiapan Belajar dan masih ada faktor-faktor internal yang lain.

Berdasarkan perkembangan kognitif, individu pada masa ini menunjukkan pemikiran yang fleksibel, individualistis dan akan menerapkan hasil pengalaman yang mereka butuhkan untuk dapat memiliki persiapan dan keyakinan diri dalam membuat keputusan akan pilihan yang hendak diambil setelah lulus. (Cooper, R.K \& Sawaf, A. 1998).

Berdasarkan tahapan perkembangannya, mahasiswa yang sedang menempuh pendidikan tingkat akhir dapat digolongkan pada usia dewasa muda. Masa dewasa muda ditandai dengan adanya keinginan untuk mengaktualisasikan segala bentuk ide dan pemikiran yang diperoleh selama menjalankan pembelajaran di pendidikan tinggi ataupun di lembaga akademi untuk persiapan masa depannya. (Cooper, R.K \& Sawaf, A. 1998).

Selanjutnya Hakim, T. (2002) menyebutkan bahwa orientasi masa depan merupakan sesuatu yang kompleks, multidimensi dan banyak hal yang terkait fenomenanya.

Nurmi (1989) dalam Agusta, Y.N. (2015) menyebutkan bahwa orientasi masa depan merupakan sesuatu yang kompleks, multidimensi dan banyak hal yang terkait fenomenanya. Ia juga menyatakan bahwa orientasi masa depan ini sangat erat kaitannya dengan harapanharapan, tujuan, standar serta rencana dan strategi yang dilakukan untuk mencapai sebuah tujuan, mimpi-mimpi dan cita-cita. Orientasi masa depan menggambarkan tentang bagaimana individu memandang dirinya dalam konteks masa depan

Berdasarkan uraian latar belakang tersebut di atas, maka penelitian ini dirancang untuk menganalisis pengaruh variabel moderator yaitu orientasi masa depan terhadap hubungan antara kebiasaan belajar, kecerdasan spirituan, kecerdasan emosional, motivasi dengan kualitas hasil belajar pada mahasiswa di Politeknik Kesehatan Surakarta Tahun 2017 


\section{METODE PENELITIAN}

Penelitian ini merupakan penelitian deskriptif korelasional yang bersifat explanatory. Adapun metode pendekatan yang digunakan dalam penelitian ini adalah cross sectional yaitu untuk mendapatkan gambaran yang senyatanya dari responden pada saat dilakukannya penelitian. (Budiman, 2011).

Sampel dalam penelitian ini adalah perwakilan mahasiswa dari tiap-tiap Jurusan di lingkungan Politeknik Kesehatan Surakarta sejumlah 365 mahasiswa.

Teknik sampling yang digunakan untuk menentukan jumlah sampel dalam penelitian ini adalah Proportional Stratified Random Sampling.(Azwar, 2009).

\section{HASIL PENELITIAN \\ Analisis Univariat}

Poltekkes Kemenkes Surakarta merupakan institusi pendidikan tinggi bidang kesehatan yang saat ini memiliki 8 Jurusan dengan 15 Program studi, dimana 8 jurusan tersebut terdiri atas Jurusan Keperawatan, Jurusan Akupunktur, Jurusan Terapi Wicara, Jurusan Fisioterapi, Jurusan Okupasi Terapi, Jurusan Ortotik Prostetik, Jurusan Kebidanan dan Jurusan Jamu. Adapun jumlah keseluruhan mahasiswa di Politeknik Kesehatan Surakarta berdasarkan data dari Adminsitrasi Akademik Poltekkes Surakarta Tahun 2017 adalah 4. 199 Mahasiswa

\section{Analisis Bivariat.}

Analisis bivariat dilakukan untuk mengetahui pengaruh antara variabel bebas dengan variabel terikat dengan menggunakan uji Kendall Tau. Hal tersebut dilakukan karena dari hasil Uji
Normalitas Data menunjukkan bahwa data tidak berdistribusi normal. (Fajar, I. et al. 2009).

Tabel 1. Hasil Analisis Bivariat FaktorFaktor yang Berhubungan dengan Kualitas Hasil Belajar Mahasiswa

\begin{tabular}{lcc}
\hline Variabel & $\boldsymbol{p}$ & $\mathbf{9 5 \%} \boldsymbol{C I}$ \\
\hline Kecerdasan Spiritual & $\mathbf{0 . 0 1 9}$ & $0.33-1.99$ \\
Motivasi & $\mathbf{0 . 0 3 1}$ & $3.6-51.55$ \\
Kecerdasan Emosional & $\mathbf{0 . 5 8 1}$ & $0.49-3.12$ \\
Kebiasaan Belajar & $\mathbf{0 . 0 3 7}$ & $1.24-7.70$ \\
\hline
\end{tabular}

a. Hubungan antara Kecerdasan Spiritual dengan Kualitas Hasil Belajar Mahasiswa Politeknik Kesehatan Surakarta.

Hasil analisis bivariat dengan uji Kendall Tau pada tabel 2 diperoleh nilai $p$ sebesar 0,019 dengan Confidence Interval 95\% antara 0.33 1.99, karena nilai koefisien korelasi yang diperoleh bertanda positif yang menunjukan terdapat hubungan yang bermakna antara Kecerdasan Spiritual dengan Kualitas Hasil Belajar Mahasiswa Politeknik Kesehatan Surakarta yang berarti semakin baik kecerdasan spiritual mahasiswa maka akan semakin baik pula nilai hasil belajarnya

b. Hubungan antara Motivasi dengan Kualitas Hasil Belajar Mahasiswa Politeknik Kesehatan Surakarta.

Hasil analisis bivariat dengan uji Kendall Tau pada tabel 2 tersebut di atas, diperoleh nilai $p$ sebesar 0,031 dengan Confidence Interval $95 \%$ antara 3.6 - 51.55, dan nilai koefisien korelasi yang diperoleh bertanda positif, yang menunjukan terdapat hubungan yang bermakna antara Motivasi dengan Kualitas Hasil Belajar Mahasiswa 
Politeknik Kesehatan Surakarta yang berarti semakin baik motivasi belajar mahasiswa maka akan semakin baik pula nilai hasil belajarnya

\section{c. Hubungan antara Kecerdasan Emosional dengan Kualitas Hasil Belajar Mahasiswa Politeknik Kesehatan Surakarta.}

Hasil analisis bivariat dengan uji Kendall Tau pada Tabel 2 diperoleh nilai $p$ sebesar 0,581 dengan Confidence Interval 95\% antara 0.49 3.12 yang menunjukan tidak terdapat hubungan yang bermakna antara Kecerdasan Emosional dengan Kualitas Hasil Belajar Mahasiswa Politeknik Kesehatan Surakarta.

d. Hubungan antara Kebiasaan Belajar dengan Kualitas Hasil Belajar Mahasiswa Politeknik Kesehatan Surakarta.

Hasil analisis bivariat dengan uji Kendall Tau pada tabel 2 tersebut di atas, diperoleh nilai $p$ sebesar 0,037 dengan Confidence Interval 95\% antara 1.24 - 7.70 dan nilai koefisien korelasi yang diperoleh bertanda positif yang menunjukan terdapat hubungan yang bermakna antara kebiasaan belajar dengan Kualitas Hasil Belajar Mahasiswa Politeknik Kesehatan Surakarta yang berarti semakin baik kebiasaan belajar mahasiswa maka akan semakin baik pula nilai hasil belajarnya.

\section{PEMBAHASAN}

a. Hubungan antara Kecerdasan Spiritual dengan Kualitas Hasil Belajar Mahasiswa Politeknik Kesehatan Surakarta.
Salah satu faktor yang mendukung keberhasilan prestasi belajar mahasiswa adalah kecerdasan. Dalam dekade terakhir ini muncul adanya Kecerdasan Spiritual yang diyakini sebagai puncaknya kecerdasan karena tidak hanya mengandalkan penalaran maupun emosi saja, namun juga menekankan aspek spiritual dalam mengarahkan manusia menuju kesuksesan dalam menjalani hidup.

Dalam perkembangannya kecerdasan ini disinyalir juga mampu menghidupkan motivasi mahasiswa dalam belajar sehingga menunjang mahasiswa dalam mencapai prestasi belajar yang diinginkan.

Menurut Agustian,AG. (2001) bahwa dalam kecerdasan spiritual terdapat prinsip-prinsip dalam membangun mental, diantaranya yaitu prinsip bintang (star principle) yang di dalamnya dipaparkan bahwa manusia sebenarnya memiliki energi yang dahsyat dalam pikiran bawah sadarnya yang bisa dijadikan sebagai sumber motivasi dalam segala hal.

Dalam kecerdasan spiritual juga memuat prinsip pembelajaran (learning principle), yang menuntun manusia untuk senantiasa mencari dan mengembangkan pengetahuan yang seluas-luasnya. Menurut Zohar dan Marshall (2001), seseorang yang mempunyai Kecerdasan Spiritual yang tinggi akan cenderung menjadi seseorang yang bertanggung jawab untuk membawakan visi dan nilai yang lebih tinggi kepada orang lain.

Dengan kata lain mahasiswa dengan kecerdasan spiritual yang tinggi akan lebih bersungguh-sungguh dalam mewujudkan cita-citanya melalui proses belajar yang ditekuninya saat 
ini. Sehingga mahasiswa yang seperti ini mempunyai potensi yang lebih besar untuk berprestasi lebih optimal.

Disamping itu, seseorang dapat memaknai setiap apa yang dilakukannya dan dapat menyelaraskan antara emosi, perasaan dan otak. Kecerdasan spiritual mengajarkan seseorang termasuk mahasiswa untuk mengekspresikan dan memberi makna pada setiap tindakannya, sehingga bila ingin menapilkan prestasi yang baik dibutuhkan kecerdasan spiritual yang baik pula.

Kecerdasan spiritual mempengaruhi tujuan seseorang dalam meraih sukses selama studi. Sesorang yang membawa makna spiritualitas dalam sekolahnya akan merasakan sekolahnya lebih berarti sehingga mendorong dan memotivasi mahasiswa untuk belajar dengan lebih baik untuk meningkatkan kemampuan atau potensinya.

\section{b. Hubungan antara Motivasi dengan} Kualitas Hasil Belajar Mahasiswa Politeknik Kesehatan Surakarta.

Motivasi erat kaitannya dengan belajar, dengan motivasi inilah mahasiswa akan meningkatkan minat, kemauan dan semangat yang tinggi dalam belajar serta tekun dalam proses belajar, dengan motivasi juga kualitas hasil belajar mahasiswa dapat diwujudkan.

Adanya hubungan antara tingkat motivasi belajar terhadap tingkat prestasi belajar mahasiswa, menunjukkan bahwa motivasi belajar perlu ditingkatkan untuk meningkatkan Prestasi Belajar dengan cara optimalisasi penerapan prinsip belajar, optimalisasi unsur dinamis balajar dan pembelajaran, optimalisasi pemanfaatan pengalaman dan kemampuan mahasiswa, serta pengembangan cita-cita dan aspirasi belajar.

\section{c. Hubungan antara Kecerdasan Emosional dengan Kualitas Hasil Belajar Mahasiswa Politeknik Kesehatan Surakarta.}

Rendahnya peranan kecerdasan emosional terhadap prestasi belajar disebabkan oleh banyaknya faktor yang mempengaruhi prestasi belajar itu sendiri. Prestasi belajar menunjukkan taraf kemampuan mahasiswa dalam mengikuti proses pembelajaran dalam waktu tertentu sesuai dengan kurikulum yang telah ditentukan. Tes prestasi belajar yang diukur adalah pengetahuan yang dimiliki mahasiswa dan bagaimana menerapkan pengetahuan tersebut untuk menyelesaikan soal-soal yang ada, baik soal hitungan maupun analisis masalah. Perbedaan budaya dalam pengekspresian emosi dalam suatu negara dengan negara lain juga dapat berpengaruh terhadap rendahnya kecerdasan emosional seseorang. Pengekspresian emosi yang dianggap benar di suatu negara mungkin dianggap tidak benar atau tidak pantas di negara lain. Khususnya di Asia, orang dianjurkan memendam dan menyembunyikan perasaan negatif.

Dalam penelitian ini, karena belum adanya skala kecerdasan emosional yang baku di Indonesia, maka penulis berusaha membuat sendiri skala kecerdasan emosional berdasarkan faktor-faktor yang diadaptasi dari teori Daniel Goleman yang digunakan di Amerika, yaitu : 
mengenali emosi diri, mengelola emosi, memotivasi diri sendiri, mengenali emosi orang lain, dan membina hubungan.

Hal tersebut terlihat pada observasi di lapangan, beberapa responden merasa kesulitan menentukan pilihan jawaban. mereka merasa ragu-ragu dalam menetapkan pilihan, sehingga ada yang mengatakan mengapa tidak ada pilihan ragu-ragu. Serta karena banyaknya jumlah pernyataan yang harus diisi dalam waktu yang terbatas, merasa bosan sehingga kurang konsentrasi dalam menjawab walau pada akhirnya mereka mampu mengisi seluruh pernyataan tersebut.

Selain itu, beberapa studi juga menegaskan terpisahnya kecerdasan emosional dari kecerdasan akademis, dan menemukan kecilnya hubungan atau tidak adanya hubungan antara nilai prestasi akademis dengan kecerdasan emosional seseorang. (Goleman, 2002 :78).

Seperti yang telah dijelaskan sebelumnya bahwa anak yang mendapatkan pendidikan emosi lebih mampu mengatasi masalah-masalah yang terjadi disekitar mereka dan mampu memenuhi tuntutan akademis di sekolah.

Kecerdasan emosional itu sendiri tidak diajarkan secara khusus di sekolah dan tidak tercatat dalam dokumen transkrip akademik, seperti nilai-nilai mata kuliah ataupun keterampilan lainnya sehingga tidak ada sumbangan secara langsung terhadap peningkatan prestasi belajar.

\section{d. Hubungan antara Kebiasaan Belajar dengan Kualitas Hasil Belajar}

\section{Mahasiswa Politeknik Kesehatan Surakarta.}

Kebiasaan belajar yang dimaksud dalam penelitian ini adalah kebiasaan yang dilakukan peserta didik dalam proses belajar sebagai mahasiswa di Politeknik Kesehatan Surakarta. Kebiasaan adalah pola tingkah laku, kondisi atau situasi tertentu yang terbentuk melalui proses belajar. Kebiasaan juga dapat diartikan sebagai bentuk tingkah laku yang tetap dan usaha menyesuaikan diri terhadap lingkungan yang mengandung unsur afektif perasaan.

Menurut Djamarah \& Zain, A. (2006), bahwa kebiasaan belajar dikelompokkan kedalam konsep dasar Delay Avoidance (DA) dan Work Method (WM). Delay Avoidance (DA) yang dimaksud adalah kebiasaan tingkah laku akademik yang berhubungan dengan ketepatan waktu dalam belajar berkaitan dengan masalah perencanaan dan kedisiplinan. Sedangkan Work Methode (WM) meliputi prosedur belajar, ketrampilan belajar dan strategi belajar yang digunakan.

Berdasarkan hasil penelitian jelas terlihat adanya hubungan antara kebiasaan belajar dengan prestasi belajar. Hubungan tersebut bersifat positif artinya semakin baik kebiasaan belajar mahasiswa akan semakin baik nilai prestasi belajarnya.

Kebiasaan belajar yang dilakukan mahasiswa dari mulai perencanaan dan kedisiplinan belajar, prosedur belajar, ketrampilan belajar serta strategi belajar dapat memberikan hasil belajar baik jika komponen-komponen tersebut dilaksanakan dengan baik pula. Hal ini didukung dengan pendapat Syah 
(2013) bahwa kebiasaan belajar merupakan salah satu faktor yang mempengaruhi kualiatas hasil belajar yang ditunjukkan dengan prestasi belajar.

\section{KESIMPULAN DAN SARAN}

Berdasarkan latar belakang, sehingga peneiti menyimpulkan:

Ada hubungan antara kebiasaan belajar, kecerdasan spiritual, dan motivasi dengan kualitas hasil belajar pada mahasiswa.

Tidak ada hubungan antara kecerdasan emosional dengan kualitas hasil belajar pada mahasiswa

Orientasi masa

depan mempengaruhi hubungan antara kebiasaan belajar, kecerdasan spiritual, kecerdasan emosional, dan motivasi dengan kualitas hasil belajar pada mahasiswa.

Sehingga untuk era global saat ini dengan memberikan kesempatan bagi mahasiswa untuk meningkatkan motivasi belajar, kemandirian belajarnya dengan menyediakan lingkungan kampus dimana mahasiswa dapat melakukan ekplorasi terhadap kemampuan kognitifnya sehingga prestasi belajarnya dapat meningkat baik.

Dan untuk tenaga pendidik hendaknya dapat meningkatkan lagi pemberian motivasi belajar agar mahasiswa lebih semangat dalam belajar.

\section{DAFTAR RUJUKAN}

Agustian, AG. 2001. Emotional Spiritual Quotient. Jakarta: Penerbit Arga.

Azwar, S. 2009. Metode Penelitian. Cetakan IX. Pustaka Pelajar Offset. Yogyakarta.

Budiman. 2011. Penelitian Kesehatan. PT. Refika Aditama. Bandung.
Cooper, R.K dan Sawaf, A. 1998. Executive EQ Kecerdasan Emosional dalam Kepemimpinan dan Organisasi (terjemahan oleh Widodo). Jakarta: Gramedia Pustaka.

Djamarah, S, B dan Zain, A. 2006. Strategi Belajar Mengajar. Jakarta: Rineka Cipta.

Fajar, I., et al, 2009. Statistika Untuk Praktisi Kesehatan. Edisi Pertama. Graha Ilmu. Yogyakarta.

Goleman, D. 2002. Emotional Intelligence (terjemahan). Jakata : PT Gramedia Pustaka Utama.

Hakim, T. 2002. Belajar secara efektif : panduan menemukan teknik belajar, memilih jurusan, dan menentukan cita-cita. Cetakan III. Jakarta : Puspa Swara

Sinetar, M. 2001. Spiritual Intelegence : Kecerdasan Spiritual. Cetakan Pertama (terjemahan Soesanto Boedi Darmo) Jakarta: PT. Elex Media Komputindo.

Syah, M. 2010. Psikologi Pendidikan. Edisi Revisi. Bandung. PT Remaja Rosdakarya.

Syah, M. 2013. Psikologi Pendidikan dengan Pendekatan Baru. Bandung: PT Remaja Rosdakarya

Zohar, D dan Marshall, I. 2001. SQ : Memanfaatkan Kecerdasan Spiritual Dalam berpikir Integralistik dan Holistik untuk Memaknai Hidup. Cetakan Kedua (Terjemahan Rahmani Astuti, Ahmad Nadjib Burhani dan Baiquni) Bandung: Penerbit Mizan 